\title{
The psychology of giving behavior in islam
}

\begin{abstract}
Waqf is a financial charitable endowment established by withholding immovable and movable properties to perpetually spend its revenue on fulfilling public needs, once the property is created as Waqf, it could never be given as gift, inherited, or sold. Traditionally, Waqf was inculcated in Muslims' culture, and has included in all walks of life. When it was the main source for various public services that been provided to communities. Therefore, Muslims in all over the world are exposed to participate in Waqf, the value of giving is one that spans all cultures and religious faiths and is an important means of establishing a social safety net for the poor. Oftentimes, charitable giving is motivated by people's attitude and behavior, religious beliefs, cultures and religious educations. This is a literature review paper that focuses on the strong connection between motives for giving and outcomes of giving. The purpose is to shed light on some of the key expressions of giving in Islam, and the psychology of giving that is quite difficult to determine in most of the studies. Some motives and effects of giving are easy to explain and the wisdom behind them is clear. On the other hand some of these phenomena's are hard to explain. However Islam stresses that giving charity increases our wealth, and makes the mercy of Allah befall on us. The findings of this study signified that the major motives for giving are behavior, attitude, faith (belief), and education. And the outcomes of giving are God blessing, more rewards, and psychological comfort that can be perceived from happiness and joy of giving as well as self-satisfaction. Hence, it is highly advisable to look comprehensively at this topic and introduce an effective framework that can help people to have better understanding on the psychology of giving.
\end{abstract}

Keywords: Waqf, Motives for Giving, Outcomes of Giving

\author{
Volume 2 Issue 2 - 2018
}

\author{
Shadiya Mohamed S Baqutayan,' Magda \\ Ismail A Mohsin, ${ }^{2}$ Akbariah Mohd Mahdzir, \\ Aini Suzana Ariffin' \\ 'Department of Technology and Innovation Policy, University \\ Technology Malaysia, Malaysia \\ ${ }^{2}$ Department of Islamic Economics and Finance, International \\ Islamic University of Malaysia, Malaysia
}

Correspondence: Shadiya Mohamed S Baqutayan, Department of Technology and Innovation Policy, University Technology Malaysia, Malaysia, Tel +60 3-2180 5023,

Email Shadiya.kl@utm.my

Received: March 17, 2018 | Published: April 09, 2018

\section{Introduction}

'Who is he that will loan to Allah a beautiful loan which Allah will double unto his credit and multiply it many times?' [2:245]. It is very important to start with the above verse that teaches us the importance of generously giving to the poor and needy. It help us to establish a better understanding of the psychological views that underlie charitable giving intention, that also plays an important role in the elicitation and stimulation of charitable giving behavior. ${ }^{1}$ Islam, like other religions, enjoins its followers to 'give' for individual and societal well-being. The three main institutionalized instruments of Islamic philanthropy and redistribution of wealth are Sadaqa (charity), Zakat (poor tax) and Waqf (trust). ${ }^{2}$ Giving Zakat, Sadaqah, or/and participating in Waqf is viewed as "compulsory and important charity"; it is the responsibility of those who have received their wealth from God to respond to those members of the community in need. The whole concept of wealth is considered in Islam as a gift from God. God, who provided it to the person, made a portion of it for the poor, so the poor have a right over one's wealth. ${ }^{3}$ The notion of giving, especially giving and helping those in need, is so entrenched in Islam. According to By Relkhatib, ${ }^{4}$ the Almighty promises us that if we train ourselves to give in times of ease and hardship, our sustenance will increase. Giving awakens our souls and triggers genuine concern for the well-being of others. Research indicates that helping others lessens anxiety and increases positive feelings and feelings of satisfaction. But is this enough to explain the phenomenon of generosity?. ${ }^{5}$ The love of good deed is the way to the happiness, and the culture of giving stems from inside. People who keen to do volunteer work are always been push by their values and ethics that embodied through behaviors. And the volunteer work varies in size, shape, trends and motives from one society to another. In terms of size, it is less in periods of stability and calm, and increases in times of disasters and wars. Then in terms of form, it may be an effort or a donation of money. In terms of direction, it may be automatic, or directed by the State in social, educational, or developmental activities; and in terms of its motives, it may be psychological, social or political. As a result, it generates selfsatisfaction, God blessing, people's happiness, and societal wellbeing.

The idea of "giving culture" with its principles, dimensions, and values is considered the basic for comprehensive development in Islam. Therefore, there are several ways to promote giving behavior and donation among Muslims. One of the imperative methods of charitable behavior in Islam is creating Waqf. Literally Waqf is derived from Arabic word "Waqafe" which means to hold, confinement, or prohibition. Waqf means forbidding movement or exchange of something and must have perpetuity. ${ }^{6}$ According Magda Ismail et al. ${ }^{7}$ Waqf is a financial charitable act established by withholding immovable and movable properties to perpetually spend its revenue on fulfilling public or family needs, depending on the preferences of and conditions set by the founder. Once the property is created as Waqf, it can never be given as gift, inherited, or sold. It belongs to Allah (swt), and the Waqf property always remains intact. Only its generated revenue is channeled to the beneficiaries. In the Islamic history we can see great pictures and useful lessons about the status of Waqf and its impact on supporting the development of the Muslim community. Awqaf were inculcated in Muslims' culture, and have included in all walks of life, and it was a source of funding for the Muslims over the centuries, because of the large endowments, that 
took place during our prophet and his companions. At this point, we need to inculcate the culture of Waqf among Muslim community, and reinforce people to participate in and create $W a q f{ }^{8}$

\section{An overview of the study}

For centuries humans have taught that enormous benefits associated with giving, donating, and charitable behavior. In fact, religious teachings have long argued that giving behavior associates with personal satisfaction and leads to prosperity. In fact, creating Waqf is kind of charity which leads to draw a close relationship to God, if followed with good intention and sincere desire. Ibn al-Qayyim stated in Zādul Ma'ād regarding our Messenger Muhammad (PBH) that he was the most generous of people in giving charity, and that he did not think anything too valuable or anything too insignificant to give in charity. Rather if anyone was to ask for something then he (PBH) would give it to them. Whether it was little or whether it was great. His happiness and his joy in giving were greater than the joy of the one who was receiving that charity. This shows the tremendous Eemān (faith) that Allāh's Messenger (PBH) had. This is because he hoped for the reward from Allāh (SWT), and he took the enjoyment in helping others as a mean to self-satisfaction. According to Anik et al. ${ }^{10}$ helping others takes countless forms and ensures countless motivations; from deep-rooted empathy to a more calculated desire for public recognition. Additionally, Abdul Rahman Mohammed Al-Qahtani ${ }^{11}$ stated that when a person does voluntary work for no reasons, there must be something in return, the return is not necessarily to be something material, but it may be something incorporeal; in the sense that he/she feels satisfied with oneself, feel that they are offering something to the community, and as a result he/she feels a psychological comfort.

\section{Methodology}

The methodology of this article is on document analysis of all literature available on giving behavior, creating Waqf, and participating in charity activities. To achieve the aim and the objectives of this paper, the study therefore includes a comprehensive literature reviews that involves collecting information relevant to the study from previous publications, research papers, and all other secondary data that are useful for this study.

\section{Literature review}

In this paper, researcher talks about two important issues; one is the "motives" for giving, and the other is the "outcomes" of giving behavior, as detailed in the following:

\section{The motives for giving}

\section{Social norms and individual behavior}

Since human behavior entails good potentials and expressed capacity of mental, physical, and social activities, it will become obviously that Islamic spirituality plays a lively role in shaping the behavior of the Muslims. Individual behavior is a logical process where elements such as attitude, norms, and behavioral control influence individual. ${ }^{12}$ Indeed, Islam as a comprehensive way of life encompasses a complete moral system that is an important aspect of its world-view. We live in an age where good and evil are often looked at as relative concepts. Islam however, holds that moral positions are not relative, and instead, defines a universal standard by which actions may be deemed moral or immoral. Then good behavior and good morals are a great worship in Islam. The Prophet (PBUH) said: "I was sent only to complete the best behavior and best characters." Social norms play an important role in social behavior, with individuals often motivated to act in accordance with perceived social norms. Social norms regulate social life, aiding in restricting selfish impulses in favor of collective outcomes. Therefore, individual behaviors are more likely to be influenced by social norms.

The guiding principle for the behavior of a Muslim is what the Qur'an refers to as Al'Amal Assalih or virtuous deeds. This term covers all deeds, not just the outward acts of worship. Doing good deed and having the right belief go hand in hand in Islam. In fact, practicing the good deed is the proof of having the right belief in the heart. This is why the Holy Quran speaks of true Muslims very often as "those who believe and do good deeds". Both the Quran and the Holy Prophet have told Muslims that the best among them is that person who shows the best behavior towards other people. Giving charity is one of the best behaviors towards other as well as major obligations in Islam and the strongest character of Muslim. Giving is an ethic that was encouraged by our religion; thus individuals in Islam are valued by their ethical behaviors in preference to what they produce. People are judged by their relationships to those who are close to them. It does not matter how much a person owns or who their father's tribe, language, or country is. Islam teaches that people are judged only on things they have control over and ways they deal with others. In Islam there are no second-class people except those who intend to deviate from Islamic values and persist in doing so. These values, if applied, will influence people's feelings about themselves that could affect their mental health and may stimulate efforts toward selfimprovement that could dispel feelings of emptiness or worthlessness. Therefore, a Muslim is constantly encouraged to perform charitable behavior, and strong Muslim norm endorses giving to the needy. The Prophet Muhammad (PBUH) said: "Even a smile is charity."

\section{Religion "beliefs" (iman/faith)}

Giving charity is the proof of faith, as those who are close to God are always seeking his love through giving. The messenger of Allah (PBUH) said: "Sadaqah is a proof." (Narrated by Muslim in hadith no. 223) According to An Nawawee: "It means the proof or evidence of the true faith the giver possesses. Hence Sadaqa is termed likewise, because it is the proof of the truth of his faith. ${ }^{13}$ The Holy Quran associates giving charity with affirmation of faith and withholding with rejection of faith. "So, he who gives in charity and fears God and in all sincerity testifies to the best. We will indeed make smooth for him the path to bliss." (92:5-10). Charity giving is a virtuous deed in Islam and considered a proof of one's faith (Iman). Abu Malik Al Ashari has quoted Allah's Messenger Mohammed the Prophet as saying, "Cleanliness is half of faith. 'Alhamdulillah' (Praise be to Allah) and 'Subhan Allah' (Glory to Allah) fill up the gap between Heaven and Earth. Prayer is a light. Charity is proof (of one's faith). Endurance is brightness and the Holy Quran is proof on your behalf or against you."Religious factor has been reported as one of the important factors in influencing various behaviors in Islamic environment. In the case of paying zakat, Nur Barizah Abu Bakar \& Hafiz Majdi Abdul Rashid (2010) reported that religious value significantly influences this compliance behavior. Besides, Amirul Faiz Osman et al. ${ }^{14}$ Amirul Faiz Osman ${ }^{15}$ in another study also indicated significant relationship between religious factors and waqf giving behavior. The more we give, the more we increase our iman and thus expect Allah's rewards in this world and in the next. Giving charity does not decrease once 
wealth but instead Allah increases it. "Allah will deprive usury of all blessing, but will give increase for deeds of charity: for He loves not creatures ungrateful and wicked." (Quran 2: 276) The individual motivation for paying alms, for instance, shows that the spiritual and religious motives dominate the giving among Muslims. The predominance of individual and parochial motivations has led some researchers to observe that such giving leads poor people to help the poor and rich to help the relatively rich. This parochial orientation to religiously motivated giving may prevent the poverty from exploding but it is not likely to have any significant impact on social justice. ${ }^{16}$

\section{Significance of culture}

If the zakat obligation is able to create safe and stable societies, voluntary and ongoing charity (Waqf) contribute to more compassionate and humane societies where the number of victims of poverty, disease, unemployment and others in need of lasting humanitarian tender increases. Although the ongoing charity is not obligatory, it is one of the most important humanitarian duties that the Prophet (PBUH) urged to help needy people, to help the poor and the weak and to spread the role of science that brings people out of darkness. And because Zakat alone may not be sufficed in some societies where the poor are increasing, voluntary charity and crating Waqf play a great role to achieve these noble humanitarian goals. Therefore, prophet Muhammad (PBUH) encouraged the giving culture, asked Muslims to participate in this activity, and made it from to which man gets closer to Allah (S. W. T). The development of Waqf culture over the centuries has reached a stage where, what we call today as municipal facilities-welfare, health and education were financed almost entirely by Waqf institution. ${ }^{17}$ But now there is a disruptive in the existence of Waqf culture among Muslim societies, exception of the funds suspended since hundreds and tens of years. You will not find these days a chandelier that easily suspended part of his property for the benefit of charity projects. There is no doubt that the absence of the role of Waqf has had a profound impact on the spread of serious social problems: such as poverty, unemployment, disease, spinsterhood, and declining the value of education. When Waqf in the past was spent on the poor, trained the unemployed, educated the needy, treated patients, and helped young men and women to marry. But with absents of Waqf culture, the contemporary Muslim society faces negative phenomena. And at a time when this culture is absent in Islamic societies, it is spread in the non-Muslim communities. ${ }^{18}$ Therefore, there is a need to work hard on the reformation of Waqf culture among Muslim communities. Culture affects the individual attitude and behaviors. The intentions to donate have been studied extensively under various cultural contexts. ${ }^{19,20}$ It is believed that an individual's emotions, cognition, and behaviors are formed by the local culture. ${ }^{21}$ This also entails that the behavior towards the intention to donate will also vary from culture to culture. ${ }^{11}$ Therefore, it is highly encouraged in this literature the need for reforming $W a q f$ culture in Muslim communities.

\section{Importance of religious education}

The impact of religious education on individuals' monetary donation can be viewed through its impact on the general human behavior. According to Mokhlis ${ }^{22}$ religious education is an important cultural factor to study because it is one of the most universal and influential social institutions impacting on peoples' behavior at both an individual and societal levels. Indeed, religion is positively related to altruism value and pro-social behaviors. ${ }^{23}$ Certainly, one may instead argue that individuals may be more likely to do charity work if they are part of a close-knit faith group where there is the pressure to conform to the norm of helping those in need. ${ }^{24}$ Therefore, the influence of religion affects the psychological disposition of the individual, as well as their physical actions. Religious educations play an important role and are often highly effective in bringing people together to become active volunteers. Various religions emphasize the responsibility of helping others. ${ }^{25,26}$ Many people volunteer, though in different ways, inspired by their religious faiths to serve the needy. ${ }^{27}$ Likewise, previous research on charitable giving indicated that there are many factors influencing charitable giving. Giving to charity is positively related to level of education, as well as being a member in religious group. ${ }^{28,29}$ And as mentioned earlier, religious participation has been found to significantly motivate donation and volunteering. For example, actively participating in religious groups, individual members can develop the social networks and skills. ${ }^{19}$

\section{The outcome of giving behavior}

\section{God blessing}

The personal sacrifice of giving one's possessions, no matter how small, for the sake of helping those in needs is a blessing and means purifying our souls and wealth. The endowment (Waqf) is one of the greatest acts in which the Muslim draws closer to Allah (swt), and it is the best of the act, whether it is a Waqf for public bodies, such as the poor, and students, or a cessation of kinship and offspring. The legitimacy of this act was indicated in the Holy Quran, detailed by the hadith of Prophet Muhammad (saw), and applied by the Companions, may Allah be pleased with them. Therefore, Allah encouraged it as a way to Allah's blessing. And the evidence from the Quran, the words of Allah (swt):

"By no means shall ye attain righteousness unless ye give (freely) of that which ye love; and whatever ye give, of a truth God Knowth it well” (surah al-'imran 3:92).

The charity givers can see the blessing of God from his/her wealth, as the wealth will be blessed, and the messenger of Allah-peace and prayer of Allah be upon him (pbuh)- said:

"Charity does not decrease wealth; no one forgives another except that Allah increases his honor." (Narrated by Muslim, no. 2588)

What is the meaning of not decreasing in wealth? Imam An Nawawee explained in his work 'Syarh Shahih Muslim,' that: "The scholars mentioned that it means two things: First, the wealth will be blessed and protected from dangers. Thus the decrease will be covered with this abstract bless. It can be felt by senses, and habits. Second, if in fact the wealth looks decreased, this decreasing will be covered by the rewards of giving charity (Waqf or/and alms), and the rewards indeed will be double-folded to many times."

\section{Psychological comfort}

It is stated in Islamway ${ }^{30}$ that when a Muslim participating in Zakat, he/she feels psychological comfort and happiness. This can also be the case for other charity giving such as creating Waqf and paying Sadaqah. The psychological comfort can be perceived from happiness and joy of giving as well as self-satisfaction.

\section{Happiness and joy of giving}

Even though happiness is perhaps one of the most important things in life, science still cannot explain much about it. Happiness in Islam can be found in the comfort that comes from being upon the truth. It 
can be achieved by sincere worship, hastening to do virtuous, noble, and beautiful deeds, and by performing acts of kindness or giving charity. These things all have the potential to make us happy, every day, under any circumstances. Even giving the smallest charity, in order to please God, can bring a smile to your face and a feeling of joy to your heart. ${ }^{31}$ Furthermore, those who truly believe in Allah and in His ability to resurrect them for reckoning would behave in a good way during their first lifetime on Earth. As a result, they will be rewarded with a good life here, by living in happiness, and in the hereafter by entering God's Paradise and enjoying a happy life there forever, as we read in Verse 16: 97 of the Holy Quran."Whoever does righteousness, whether male or female, while he is a believer - We will surely cause him to live a good life, and We will surely give them their reward (in the Hereafter) according to the best of what they used to do" (Al-Na'hl: 97).

Giving and charitable donations, may promote happiness. According to Ihsan ${ }^{32}$ the true happiness is in providing happiness, joy, and love to others. Once the person gives, he/she is likely to receive psychological and social benefits from their donation, such as feelings of joy or warm glow, enhanced self-esteem, and increased social status. $^{33}$

\section{Self-satisfaction}

Giving money, time, and knowledge are all acts of altruism that the person will be rewarded. Furthermore, giving openhandedly and freely brings self-satisfaction of not only having helped others but having pleased Allah (swt) in our good actions. ${ }^{34,35}$ The Qur'an is very clear in presenting the message that we essentially help ourselves by helping others."Whoever recommends and helps a good cause becomes a partner therein, and whoever recommends and helps an evil cause shares in its burden and Allah has power over all things" (4:85). A person spends his wealth in this world to gain personal satisfaction, happiness, and reward from Allah (swt). According to Hibbert and Horne $^{36}$ givers may gain several benefits after donating, including self-esteem and satisfaction. Likewise, in creating Waqf, Mustafa Omar Muhammad et al. ${ }^{37}$ indicted that there are several potential determinants that promote a Muslim to be involved in waqf such as religious satisfaction, literacy of waqf, trustworthiness, demographic factor, efficient management and tax incentive.

\section{Double rewards}

Allah will double fold the reward of the charity giver, as mentioned in the Quran (Al Hadid: 18). "Verily those who give alms-be they men or women, -and give Allah a beautiful loan shall be repaid after

increasing it many times; and theirs shall be a generous reward (Figure 1)."

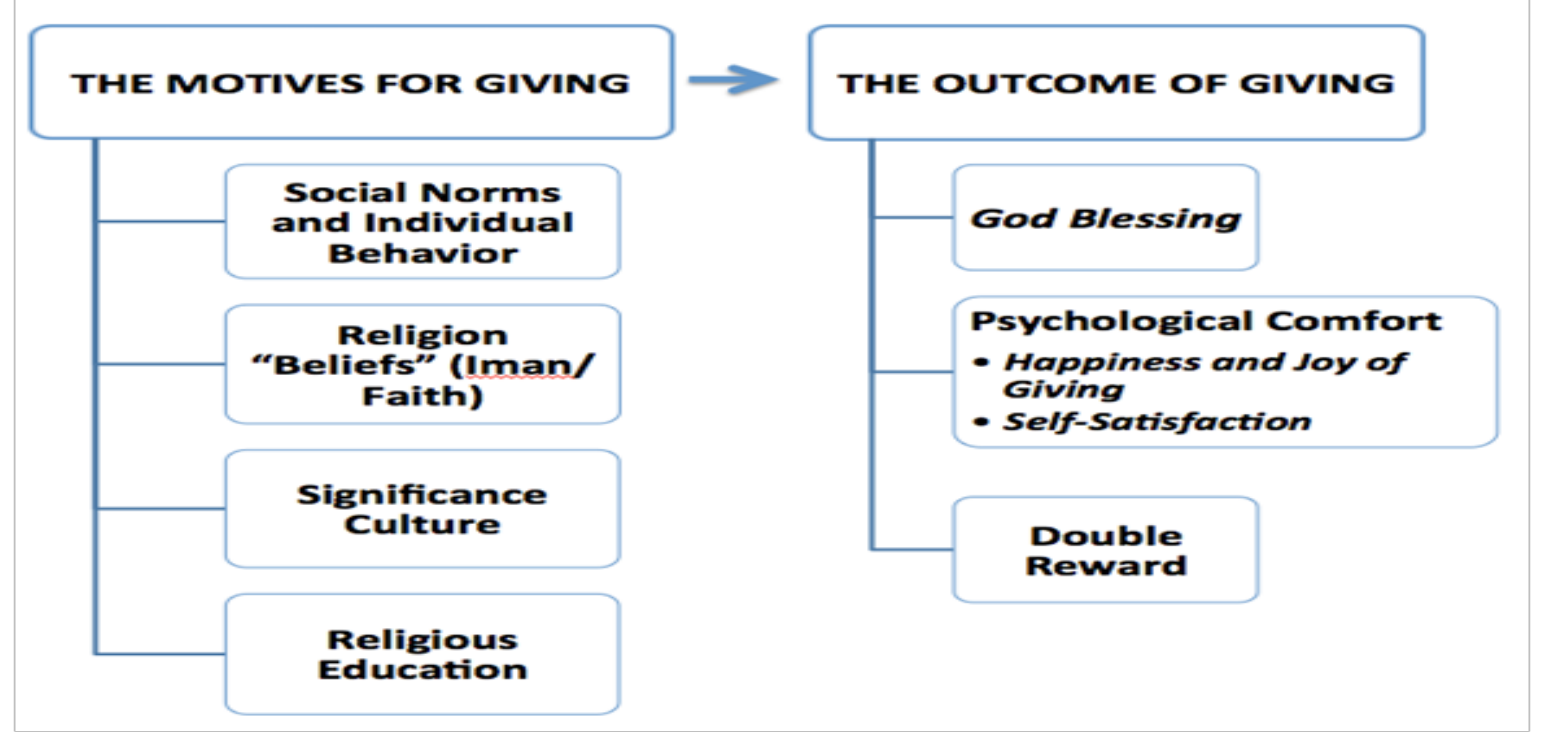

Figure I The "Motives" and "Outcomes" of giving.

\section{Conclusion}

The importance of charitable giving is mentioned throughout the Qur'an, and in many hadiths (sayings of the Prophet). Charity is a central tenet of Islam: everything one has belongs to God and therefore a Muslim is obliged to share wealth with those less fortunate. The one neat thing about giving is that it's win-win situation, the recipient, and the giver both benefit in different way. Giving in ways however small confers greater happiness than not giving at all. ${ }^{38}$ The purpose of this study is to determine the motives for giving and the outcome of giving. Based on the literatures; the human behavior, culture, faith and educational background motivate people to give. Moreover, the God blessing, happiness, and getting double rewards are the outcomes of giving. The theoretical implication for this study is to understand the psychology of giving. This study also gives practical contributions to the waqf research by identifying the motives that can influence the Muslim to participate in waqf. As the research on the psychology of waqf giving behavior are still lacking, therefore, more studies are required on this issue.

\section{Acknowledgement}

I would like to express my special thanks of gratitude to The Ministry of Education as well as Universiti Teknologi Malaysia (UTM) who gave me the golden opportunity to do this wonderful project (Fundamental research grants), which also helped me in doing a lot of publications. I came to know about so many new things I am really thankful to them. My sincere thank also to all my colleagues who kindly provided valuable and helpful comments of this paper. 


\section{Conflict of interest}

None.

\section{References}

1. Linden SVD. "Charitable Intent: A Moral or Social Construct? A Revised Theory of Planned Behaviour Model". Current Psychology 2011;30(4):355-374.

2. Riaz Hassan. Giving and Gaining: Philanthropy and Social Justice In Muslim Societies. Lahore Journal of Policy Studies. 2007;1(1):25-34.

3. Imam Kamil Mufti. The Third Pillar of Islam: Compulsory Charity. The religion of Islam;2006.

4. Relkhatib. The Importance of Charity and Giving in Islam. Islamic Relief: USA; 2010.

5. SACAP. Why giving makes us happy. South Africa; 2015.

6. Kahf M. Towards the Revival of Awqaf : A Few Fiqhi Issues to Reconsider. USA;1999:1-16.

7. Magda Ismail A, Hisham D, Murat C, et al. Financing the Development of Old Waqf Properties; Classical Principles and Innovative Practices around the World. Palgrave Macmillan: New York;2016.

8. Salman bin Mohammed Al Omari. The absence of waqf culture. USA; 2017.

9. Ibn al Qayyim. Stated in Zādul Ma'ād. Darul Kitab Al-Arabi: Beirut;2005.

10. Anik L, Aknin LB, Norton MI, et al. Feeling Good about Giving: The Benefits (and Costs) of Self-Interested Charitable Behavior. 2009:1-23.

11. Abdul Rahman Mohammed Al Qahtani. The Culture of voluntary work is missing. 2007.

12. Muhammad Kashif, Syamsulang Sarifuddin, Azizah Hassan. Charity donation: intentions and behaviour. Marketing Intelligence \& Planning. 2015;33(1):90-102.

13. Yulian Purnama. The Power of Shadaqa (Giving charity) in The Month of Ramadan. USA;2012.

14. Amirul Faiz Osman. An Analysis of Cash Waqf Participation Among Young Intellectuals. International Institute of Social and Economic Sciences: Czech Republic, Istanbul;2014.

15. Amirul Faiz Osman, Mustafa Omar Mohammed, Aiman Fadzil. Factor Influencing Cash Waqf Giving Behavior: A Revised Theory of Planned Behavior. Journal of Global Business and Social Entrepreneurship. 2015;1(1):33-48.

16. Carkoglu A. Philanthropy in Turkey. Turkey; 2004: 80p.

17. Hoexter M. Waqf studies in the twentieth century: The state of the art JESHO.1998;41(4):474-495.

18. Samia Al Saati. Waqf departed from Muslims community and applied in Westerners society. UAE:2010.

19. Chan RYK, Lau LBY. Explaining green purchasing behaviour: cross-cultural study on American and Chinese consumers. Journal of International Consumer Marketing. 2001;14(2/3):9-40.
20. Park HS, Yun D, Smith SW. et al. Family communication patterns and willingness to engage in family discussion about organ donation in the United States. Global Journal of Health Science. 2010;2(2):61-71.

21. Markus HR, Kitayama S. Culture and the self: implications for cognition, emotion, and motivation. Psychological Review. 1991;98(2):224-253.

22. Mokhlis S. Relevancy and measurement of religiosity in consumer behaviour research. International Business Research. 2009;2(39):75-84.

23. Carlo G. et al. The multidimensionality of prosocial behaviors and evidence of measurement equivalence in Mexican American and European American early adolescents. Journal of Research on Adolescence. 2010;20(2):334-358.

24. Taniguchi H, Thomas LD. The Influences of Religious Attitudes on Volunteering. Voluntas. 2011;22(2):335-355.

25. Wilson J, Musick M. Who cares? Toward an integrated theory of volunteer work. American. Sociological Review. 1997;62(5):694-713.

26. Wuthnow R. Mobilizing civic engagement: The changing impact of religious involvement. In Skocpol T, Fiorina MP, editors. Civic engagement in American democracy. Brookings Institution Press: USA;1999:331-363.

27. Wuthnow R. God and mammon in America. New York: The Free Press;1994. 364p.

28. Bekkers Rene. Giving and Volunteering in the Netherlands: Sociological and Psychological Perspectives. Netherlands; 2004.300p.

29. Borgonovi, Francesca. Divided We Stand, United We Fall: Religious Pluralism, Giving, and Volunteering. American Sociological Review. 2008;73(1):105-28.

30. Islamway. Zakah is happiness. 2012.

31. Muham Taqra, Lavadastra Sakura. Concept of happiness in Islam religion. Amazon Digital Services LLC: USA; 2015:1-17.

32. Ihsan. How to Make Allah Happy in Islam; 2013.

33. Bennett R. Factors underlying the inclination to donate to particular types of charity. International Journal of Nonprofit and Voluntary Sector Marketing. 2003;8(1):12-29.

34. Sumayya Mehmood, Taufik Ali Valiante. Positive Psychology Exercises and Islamic Practices. Sound vision: USA; 2017.

35. Vali Nasser. The Psychology of Happiness and Well-Being. LuLu: USA; 2010. 108p.

36. Hibbert S, Horne S. "Giving to charity: questioning the donor decision process". Journal of Consumer Marketing. 1996;13(2):4-13.

37. Mustafa Omar Muhammad, Amirul Faiz Osman, Sheila Nu Nu Htay. Determinants of Cash Waqf Giving in Malaysia: Survey of Selected Works. In: Workshop Antarbangsa Pembangunan Berteraskan Islam V: Indonesia; 2012.186-243.

38. Gispen WH. Giving and Volunteering in the Netherlands Sociological and Psychological Perspectives. Utrecht University: Netherlands; 2004. 300p. 